\title{
Planning a market exit strategy for manufacturers of consumer goods when entering foreign markets
}

\section{Maik DŐRING}

\section{Feuma, Germany}

\begin{abstract}
:
Aim: The internal market for manufacturers of consumer products companies is often too small in order to grant long-term success. Therefore, companies expand and enter foreign markets. This paper presents a planning process for market penetration for the selected foreign market, which will show the possibility of a withdrawal and shows also whether an exit scenario is planned by manufacturers of consumer products and when companies tend to think about a market exit.
\end{abstract}

Design / Research methods: First, the literature was studied. Based on this, hypothesis were prepared. This was followed by a telephone survey of decision-makers from German manufacturers of the consumer products companies.

Conclusions / findings: A planning process for market penetration was developed, which shows next to the market entry also the market exit. Additional this paper shows that manufacturers of consumer products companies can be better prepared for a market exit than companies without an exit strategy, in particular, if the manufacturer sets out relevant economic parameters for the foreign market which determine whether to remain in the market or leave.

Originality / value of the article: When analysing literature on planning processes for market entry, it becomes clear that an exit strategy is not planned. This may indicate that the authors did not consider a market exit and/or anticipate this as a worst case in their market entry assumption.

Implications of the research: The last market entry of the surveyed companies usually occurred recently. For market exit results to be determined, a further consultation of the companies examined should be undertaken over a longer period of time.

Keywords: Manufacturers of consumer goods, foreign markets, planning process for market penetration, market exit

JEL: L20, L66, L67, L68.

E-mail: doering@feuma.de.

Received: 16-11-2015, Revised: 18-07-2016, Accepted: 18-07-2016.

doi: http://dx.doi.org/10.29015/cerem.90 


\section{Introduction, problem definition and objective}

Manufacturers of consumer goods penetrate foreign markets. The reasons may be manifold, such as the saturation of the internal market, and/or the extension of the product life cycle and/or the development of a market position as well as following competitors into an external market (von Behr 2004: 45-98; Meffert, Bolz 1994: 94ff.).

Companies in the Consumer Goods Industry (CGI) can also fail with their products abroad, as the example of Henkel in China shows. With brands of detergent like Persil and Spee, but also with local brands such as Wipp or Tianqing, Henkel withdrew in 2008 from the local market. The reason for Henkel's withdrawal was that the target profit for the company was impossible to reach. Domestic competitors work largely with rock-bottom prices for their products and low profits (Brück 2011: 3).

The possibility of failure in the new foreign market and a potential loss of image in its home market therefore makes the decision problematic for a new market penetration. The market entry therefore requires thorough thinking and planning (Kutschker, Schmid 2008: 424; Welge, Holtbrügge 2006: 53-94; Perlitz 2004: 66; Ruzzier et al. 2006: 476-497).

When analysing literature on planning processes for market entry, it becomes clear that an exit strategy is not planned (the processes, see Neubert 2006: 53ff.; Renggli, Martin 2006: 399; Fuchs, Apfelthaler 2009: 267ff.; Root 1998: 2-4). This may indicate that the authors did not consider a market exit and/or anticipate this as a WORST CASE in their market entry assumption.

In the light of these considerations, we will undertake the analysis of market entries into foreign markets for companies in the consumer goods industry. At the same time, a planning process for market penetration will be developed, that will show the possibility of a withdrawal. A study carried out by the author with policymakers in 100 companies in the consumer goods industry, will provide results for the market entry and exit. The focus of this publication will be on the results of market exits. 
In the following section, the theoretical consideration will be discussed. The third section will examine concrete results. In the last section, the summary of the results will be presented.

\section{Theoretical considerations}

Before showing actual results - in relation to the topic of publication - a digression into the essential concepts will be made. Then follows a development on the market entry planning process.

\subsection{Presentation of the most important concepts}

The concepts defined in this sub-section are of central importance for this research work. The terms referred to in the first chapter are already relevant: manufacturers of consumer goods, market, market entry and exit.

Manufacturers of consumer goods are companies which produce durable goods and consumer goods. The difference between consumer goods and durable goods is in the purpose (Kuß 2006: 10). When goods are purchased for day-to-day needs, they are considered to be consumer goods because they will be purchased again by the consumers in short purchasing cycles (Westphal 1991: 43ff.). When products are purchased for long-term use, they are considered to be durable goods (Jenner 1994: 110; Fischbach 1992: 13).

In literature, the term market is defined by the following, often unanimous explanations such as, for example, those from Grossekettler et al. and Fischbach: "The term market, used in economics, is derived from the idea of a weekly or a securities market. If you were to generalise these expectations in such a way that you're not only considering purchasing and selling activities for a particular product at a specified place and time, but also activities such as the shipping of goods or including the phonele-commerce, you would arrive at a definition that focuses on sales of products that are essentially material. This goods-oriented market definition is: "We see the market as a sort of meeting of supply and demand for a particular kind of good (Grossekettler et al. 2005: 158)." "In the abstract 
sense, the market that is important today, is the intellectual expression of all purchase and sales transactions for a particular good (Fischbach 1992: 339)."

In summary, the term market designates the meeting of supply and demand on the procurement and/or sales market for a particular good, whereby prices are being formed (Meffert et al. 2008: 3; Sander 2004: 21; Kortmann 2003: 19). The goods can be consumer goods, capital goods, land, money or work itself (Sander 2004: 21).

The research focuses on the analysis of companies in the consumer goods industry (CGI). Companies in the services sector, which, in essence, provide services and/or activities will not be analysed (Burr, Stephan 2006: 17ff.).

In the procurement market, the company can obtain these goods for their own production (Large 2009: 101; Rüdrich et al. 2004: 11-84). In the sales market, the company can try to sell goods (Kuß 2006: 28ff.).

Market entry refers to the opportunity for companies to penetrate a new market in order to participate as a buyer or seller (Oelsnitz 2000: 2-9). The market entry can be performed in the home country, in a neighbouring country but can also take place in remote areas (Jenner 2000: 121-136). Under market entry, we understand entry into a foreign market as a concrete event or even a period of time that may include multiple activities (Kutschker, Schmid 2008: 1106; Michaeli 2008: 434). In the context of this study, the market entry is seen as a period of time. The beginning of the market entry is the introduction of the product, the conclusion of the entry is its sale.

Market exit is the time at which a company withdraws from a market (Porter 2008: 243). A definition of the factors leading to a market exit is not known. So, for example, the exit can occur when one or more targets are not achieved. 


\subsection{Theories, approaches and concepts, and a decision on a theoretical concept for this study}

Behavioural theories ${ }^{1}$ show limits for decisions in terms of rationality for organisations, but also for their decision makers. Thus, decision-making by the company about internationalisation can also be a rather rational or even irrational process, in some respects (Siedenbiedel 2008: 66). The theories and approaches to internationalisation $^{2}$ are, however, rather explanatory models, seldom decision models. This means that these theories are largely looking for criteria on how to achieve the internationalisation of companies (Perlitz 2004: 115-118).

The actual behaviour of companies entering new markets is not discussed in the above theories and approaches to internationalisation. Also, these theories and approaches often examine different aspects of internationalisation. In these theories, internationalisation was seldom analysed as to whether it was successful for businesses or not, i.e. what constitutes successful internationalisation and how it is affected by external factors (Kutschker, Schmid 2008: 471-474).

The concepts reflected in the context of this paper show that Wesnitzer's reasoning cannot solve the issues raised by this research. He has limited his study to only Eastern European countries at the time after the fall of the Berlin wall. Moreover, he suggests in his study of market entries by German companies, that explanations of the transaction cost theory, with a view to market entry strategies, apparently play no significant role in decisions to enter a new market.

A major challenge for market entry of CGI companies lies in the consumer market, where new consumers are to be won over. Therefore, it is imperative to take into account the conditions for companies entering the market, i.e. market conditions and business requirements (Macharzina, Wolf 2010: 1037; Dülfer, Jöstingmeier 2008: 134; Schmid 2006: 172). If this is not done, objectives are not always reached (Lehmann-Waffenschmidt 2006: 253). In this regard, Aharoni notes that decision makers are often faced not only with deficits in the definition of objectives, but often

\footnotetext{
${ }^{1}$ See the concept of bounded rationality, theory of organizational decision.

2 The most relevant theories in the literature: the behavioral theory of Aharoni, the product life cycle theory of Vernon, the location-based approaches, the diamond approach of Porter, the transaction costs approach, the competitive advantage theory, the eclectic paradigm of Dunning and culture models, like the Uppsala model and the study of Hofstede.
} 
also with deficits in new market information (Aharoni 1966: 49ff). Therein lies a poorly structured decision problem. Tesch provides a list of conditions to be taken into account about the market and business conditions for market entry, but that list is virtually endless (Perlitz 2004: 100) so that the complexity of the conditions to be taken into account for market entry by CGI companies, can only be guessed at. As mentioned several times above, it is also an objective of the present document to reduce this complexity to bare essentials. In the context of the study, it is to be pointed out that possible, rather limited rational decisions or even irrational decisions of companies to enter the market, are not necessarily wrong as such.

Therefore, based on the basic model of decision theory, a model is built, which represents the market entry of manufacturers of consumer goods in foreign markets. In the context of this paper, it is important to determine relevant goals, relevant options for action, relevant business requirements and relevant market conditions, with which concrete goals for market entry can be better achieved and a short-lived market entry is avoided. The planning process for market entry with an integrated market exit strategy is described in the next section.

\subsection{Planning process at the time of market entry}

Penetrating a foreign market requires planning by the management of a company (Bell et al. 2004: 23-56). To this end, the use of standardised methods or planning processes is recommended (Kutschker, Schmid 2008: 947ff.). A planning process is the establishment of a sequence within planning stages in order to achieve certain objectives (Fuchs, Unger 2007: 19; Warzecha 2004: 20; Eckrich 2003: 35$52)$.

In literature, there are several variations on the definition of a planning process in a market penetration. The planning processes differ not only in the number of process phases, but also in their respective task descriptions (the processes, see Neubert 2006: 53ff.; Renggli, Martin 2006: 399; Fuchs, Apfelthaler 2009: 267ff.; Root 1998: 2-4). 
In the context of internationalisation ${ }^{3}$, Root developed a planning process at the time of market entry. The basis for his considerations is that entry into a new foreign market requires a comprehensive plan with business principles and objectives, company resources and a company policy. For the planning and implementation phase for a market entry, Root estimates that a period of at least 3 to 5 years is required. In the first step, it should be investigated how and which products should be proposed for a market entry into a new market. The next step involves defining the management objectives, which are to be achieved in the new market. The third step defines the form of business. Before entering the market, the marketing plan must be established by the company in a fourth step (Root 1998: 2-4). However, a possible withdrawal from the market will usually not be included.

Neubert illustrates what a market process from preparation of market entry to market cultivation can look like. He associates tasks and tools with each process (Neubert 2006: 53ff). Before the planning process, consisting of four phases, namely market selection, market preparation, market entry, market development, Neubert procedes with a business potential analysis, during which the company and marketing goals are set (Neubert 2006: 57).

As the time frame for establishing the market entry targets is not revealed, it can be assumed that these objectives will be decided only at the business plan stage. In the business plan, strategies and objectives of the company, as well as requirements, plans and measures are set in a time frame of 3 to 5 years (Nagl 2011: 13ff.; Harms et al. 2008: 79-93). This timing after the final market entry decision appears, according to the author of this study, to be too late. Only on the basis of preestablished objectives can options for the market entry be developed and targets be adjusted, if necessary. It is advisable to address objectives before the final market entry decision. Neubert however does not specify when such a thing should happen within the process.

An withdrawal scenario from the market is also not considered by Neubert. Through a planned exit, sunk costs can be prevented by remaining in the foreign

\footnotetext{
${ }^{3}$ As for the internationalisation, there is on the one hand, an understanding of a process, meaning the increasing integration of companies in foreign markets, and on the other hand, the opinion of a status description, meaning the distribution of value creation activities of companies in different countries at specific times, see Glaum, M. 2007: 3-29.
} 
market (Stiglitz, Walsh 2010: 188). Sunk costs are costs that are bound to a particular corporate commitment - like location-bound investments or costs due to product-specific adaptations - and that cannot be recovered after a market exit (Büter 2010: 72; Cezanne 2005: 167; Donges, Freytag 2004: 223).

The brand-expansion-count-down process described by Renggli and Martin shows the steps to follow when opening stores in other countries as a way of market entry. The process consists of the market entry decision (phase I), the market conquest strategy (phase II), the company organisation (phase III) and the opening of a subsidiary (phase IV) (Renggli, Martin 2006: 397-409). When the target setting is to be done remains open. Also, a possible market exit is not considered here either.

Fuchs and Apfelthaler have described a process for the systematic market entry decision. This process consists of six phases. The first phase is the decision in favour of an internationalisation process, the second phase is the product decision and the third phase is the market decision. Then, the fourth phase decides whether the market entry will take place or not. In the fifth phase, the planning decision occurs with the business plan and the sixth phase focuses on the market cultivation (Fuchs, Apfelthaler 2009: 267ff.). The market entry as a separate phase and a possible withdrawal are not shown as such.

Based on the planning processes, a new planning process has now been elaborated. This can be divided into four main phases, as shown in Table 1.

\begin{tabular}{|c|c|c|c|c|c|}
\hline I & $\|$ & III & \multicolumn{3}{|c|}{ IV } \\
\hline \multirow{3}{*}{$\begin{array}{c}\text { Market } \\
\& \\
\text { Target Setting }\end{array}$} & \multirow{3}{*}{$\begin{array}{c}\text { Overall Analyses } \\
\& \\
\text { Market Entry } \\
\text { Decision }\end{array}$} & \multirow{3}{*}{$\begin{array}{c}\text { Preparation } \\
\text { Market Cultivation }\end{array}$} & \multicolumn{3}{|c|}{ Market Cultivation } \\
\hline & & & IVa & $\mathrm{IVb}$ & IVc \\
\hline & & & Markt Entry & $\begin{array}{c}\text { Market } \\
\text { Development }\end{array}$ & Market Exit \\
\hline
\end{tabular}

\section{Table 1 Planning the market entry}

Source: Author's own elaboration. 
In the market and target setting phase (phase I), the geographical selection of the target market is made, followed by the establishment of a possible date of entry and the determination of corporate and market entry targets for the market entry.

In the overall analysis, the possible options to cover these objectives in terms of market cultivation, market conditions and company requirements are explored. This will take into account the specificities of CGI when entering the new market (Emes, Gruber 2008: 303-322). In this phase II, there will be a recommendation for the market entry as a basis for the entry decision at the end of the phase. If there is any resistance in the implementation of this decision, follow-up negotiations are possible. Phase II represents the pre-examination of the subsequent stages III-IV.

In the framework of the preparation (phase III), depending on the options for market cultivation, an "action plan" for the new market needs to be defined, its implementation being essential in order to achieve the objectives. At the same time, it is possible to anticipate a possible exit scenario, if targets are not met. That is why the market cultivation is divided into market entry and market development within the newly developed process as opposed to other processes, supplemented by an exit strategy.

Within the market cultivation, the market entry is considered complete if the requirements for a continuous development of the market abroad are met, that is, if the product is accepted by the market and can be sold (Neubert 2006: 61). The implementation of the measures set out in the strategic plan for the further market strengthening and development will occur during the market development (Faix et al. 2006: 57).

In summary, the represented process shows a market entry planning for the selected foreign market. Objectives, local market conditions and company requirements are considered in the overall analysis. The market exit as part of the market analysis is added.

The extent to which German companies in the Consumer Goods Industry (CGI) plan for market entry and exit is shown in the results of this study. Based on the theoretical findings, an empirical investigation has been conducted with decision makers in 100 companies in the consumer goods industry which can provide information about the processes and background information on market entries and 
exits. The focus of this publication is on the market exit aspects, as already described above.

\section{Methodology of the presented study}

In the context of the present study, the quantitative survey method and a telephone survey using a standardised questionnaire appeared to be the most appropriate survey instrument, allowing for a structured survey. Statements of interviewees can be compared. Thus, the number of samples of quantitative results may allow statements regarding the hypotheses (Paier 2010: 101).

Telephone surveys eliminate possible travelling expenses to interview partners (Paier 2010: 99; Scholl 2009: 42). This may also explain why market and social research institutes with headquarters in Germany resort to telephone interviews, as much as possible - in addition to online surveys (ADM 2010). The time required for the interview partner to answer the questions is less than in the case of a face-to-face interview. This can also increase the willingness to participate in the interview (Schnell et al. 2011: 366).

A disadvantage of telephone interviews can be that it is not possible to use any visual aids to help in the representation of the interview topic. In addition, a telephone interview has a temporal limitation of the interview period to avoid call termination. Often, there is also an unwillingness of interview partners to respond to open and/or sensitive or delicate questions (Schnell et al. 2011: 361; Paier 2010: 101; Scholl 2009: 43).

The execution of the survey was carried out by a market research institute. The main reason for deciding on a telephone survey of decision makers through a market research institute, in this case, Foerster \& Thelen Marktforschung Feldservice $\mathrm{GmbH}$ (Bochum/Germany), and to outsource the rather non-scientific part of this market research study, was to ensure that the theoretically elaborated part of the questionnaire also works in practice. Foerster \& Thelen have the manpower, such as interviewers, who are familiar with the data collection process. Survey data can already be prepared and be made available as SPSS data set. In addition, Foerster \& 
Thelen are using CATI (Computer Assisted Telephone Interviewing). Possible refusals can be avoided and thus a higher coverage rate can be achieved.

To improve the quality of the survey, the interviewers have been trained on-site at the market research Institute. This training was conducted by the author of this study to intensively prepare the interviewers on the questions and their answers in the input mask. Each question, as well as links to other issues was discussed. Terms were explained if not known to the interviewers.

\section{Results of the study}

\subsection{General results}

The interview lasted on average about 24 minutes. An interview survey was therefore in line with the interview duration occurring in practice, namely between 10 and 30 minutes (Diekmann 2010: 504). 1739 contacts from the adjusted sample led to 100 completed interviews, which corresponds to a ratio of $5.8 \%$.

The last 100 completed market entries, which were considered by the respondents during the interview, occurred mainly in Europe. Here, in particular, the countries France, Russia and the United Kingdom are mentioned. In Asia, the focus is on entering the market in countries in East Asia such as Japan and South Korea, and in America, in the USA and Canada. Once the companies have penetrated a foreign market, they then consider the market entry finished after approximately 14 months, on average.

The majority of the surveyed companies can be considered to be small and medium-sized enterprises (SMES) (see Figure 1). According to the Institute for Small and Medium-sized Business Research (IfM), SMEs are companies with fewer than 500 employees and less than EUR 50 million annual turnover (Institute for Small and Medium-sized Business Research 2002). 


\section{Number Manufacturers of Number of employees consumer goods

$$
\mathrm{N}=94
$$

14

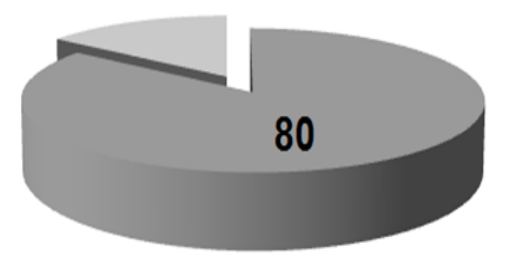

8.025

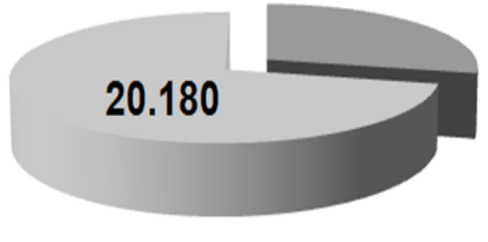

SMES*

no SMEs*

*IfM classification

\section{Figure 1. Respondent companies broken down by size (own representation based on the survey)}

The vast majority of market entries was made as an own market entry ${ }^{4}(81 \%)$. Direct export appeared to be of great relevance (69\%). Companies penetrate those markets, where they expect to have many potential customers. In addition, market entry occurred mainly in markets with strong competitors. The power of retailers was rated as "strong" by almost half of the respondents. Only every fourth company considered the power of retailers as "weak". The market in the new foreign market is often assessed as a free market with a high level of political stability and a high degree of legal security.

In answering the question as to how the distribution of products was handled in the export market, multiple answers were possible because the sale through one form of distribution does not exclude other forms of distribution, at the same time. The results show that trade accounts for more than half of product sales and direct sales through the export department for less than one third. The small balance is distributed almost equally between distribution in "shop-in-shop / own outlets", "own online shops" and "direct marketing via media". Negotiations with retailers revolved predominantly around price agreements and arrangements in terms of turnover and logistics.

Almost two thirds of respondents did not include any additional know-how for planning their market entry. These are often smaller companies. A third of these

\footnotetext{
${ }^{4}$ Own market entry: direct export, overseas branch, sales joint venture
} 
respondents envisage, however, resorting to external expertise when approaching the next market entry.

\subsection{Concrete market exit results}

The result of the survey shows that a good tenth of the companies planning to enter a market have also planned for an exit scenario. Almost one-tenth has been thinking about withdrawal after entering a new foreign market (own work/study).

One-fifth of the manufacturers who have planned for a market exit scenario before entering the market, have thought about withdrawal after having entered in the foreign market (see table 1). For those who did plan for a market exit scenario, the proportion is less than one-tenth of the manufacturers.

Among companies that have planned for a market exit scenario before entering the market, the difference between companies that have considered a market exit and those that have not, is visible in terms of the degree of turnover achievement (own work/study: Turnover is the most important market entry objective). Companies tend to think about a market exit if the sales target is not reached.

\begin{tabular}{|c|c|c|c|c|c|}
\hline \multirow{4}{*}{\multicolumn{2}{|c|}{ Feature }} & \multicolumn{4}{|c|}{$\begin{array}{l}\text { Was a market exit scenario planned prior to entering the } \\
\text { market? }\end{array}$} \\
\hline & & \multicolumn{2}{|c|}{ Yes } & \multicolumn{2}{|c|}{ No } \\
\hline & & \multicolumn{2}{|c|}{$\begin{array}{c}\text { Have you ever thought about } \\
\text { a market exit? }\end{array}$} & \multicolumn{2}{|c|}{$\begin{array}{c}\text { Have you ever thought abou } \\
\text { a market exit? }\end{array}$} \\
\hline & & Yes & No & Yes & No \\
\hline \multirow{2}{*}{$\begin{array}{l}\text { Market entry turnover } \\
\text { target } \\
{[1=\text { not achieved up to } 5=} \\
\text { fully achieved }]\end{array}$} & MV & 2.50 & 3.29 & 3.33 & 3.41 \\
\hline & $\mathrm{N}$ & 2 & 7 & 6 & 75 \\
\hline
\end{tabular}

Table 2. Comparing market exit scenario planning vs. considering market exit and target achievement for the market entry turnover target

$\mathrm{MV}=$ mean value, $\mathrm{N}=$ number

Source: author's own representation based on the survey.

This suggests that companies in the CGI, when planning for market exit scenarios, have also defined criteria for exiting the market, in addition to the market exit itself. Thus, the market withdrawal scenarios can be aligned quantitatively with 
economic parameters. Specific limits are set for remaining in the market. When falling short of these limits, the company will withdraw from the market.

The survey of 100 companies shows that almost all respondents CG manufacturers from Germany are still active in foreign markets. Only one company withdrew.

The market entry took place in 2010 with indirect export as a form of business. The exit occurred in the same year. The reason for the withdrawal was insufficient sales in the foreign market.

Further analysis on market exits is not possible at this point, because the number of cases of market exits is quite low.

\section{Discussion of findings}

The study carried out on the consumer goods industry provides results for market entry and exit. Most of the manufacturers have not withdrawn from the market - as this study shows. Since the latest market entry of the company was queried, a crucial reason for being persistent -without market exit- may reside in the fact that the penetration is still fairly recent.

The market entry was mostly operated as an own market entry. This may be related to the marketing of products "Made in Germany". A possible partner -as a no own market entry ${ }^{5}$ - is likely to be less trusted than own employees. When entering a foreign market, the goal is to find a partner who guarantees the sale of products. Trusting your partners plays an important role. This trust does not seem very strong.

An own market entry often means higher investments in the foreign market. Investments should pay off in the long term. A failure in the international market through a market exit- was probably not even considered by the surveyed companies.

According to this study, the duration of consideration for entering a new market in a relevant target market was approximately 24 months, on average. The reflection

\footnotetext{
${ }^{5}$ No own market entry: indirect export, franchising.
} 
time does not inevitably correspond to the planning time, but includes it and can go beyond it. However, this duration can also be due to the financial flexibility of the company being low and/or by the decision-makers having not gathered enough market entry experience and being hesitant in their final decision. In addition, it can be assumed that the main goal of the reflection period, the decision to enter the market and plan for it, is a successful market entry, with the achievement of sales and no early withdrawal from the market.

Additional know-how in the planning phase to enter the market was barely involved. Since these were mostly small companies, this may be due to the costs for accessing external expertise or to their reluctance to hire consultants.

As shown in this study, the market in the new foreign market is often assessed as a free market with a high level of political stability and a high degree of legal security. This means that companies penetrate markets in which hardly any restrictions are expected, which can affect the sales of products and a possible market exit.

Also, entry took place into countries around the world, but seldom in China. Possibly, manufacturers of consumer goods -given the product piracy in Chinarather fear a potential market exit, so that market entry is already excluded from the start.

It is evident that the sale of products of new market participants largely requires distribution via retail trade. Therefore, agreements were also mostly concluded with these. This can be a further option to help secure a market position in the new international market.

The study shows that manufacturers of consumer products with planned market exit scenarios, will consider a market exit if the objectives are not achieved. They can be better prepared for a market withdrawal than companies without an exit strategy, in particular, if the manufacturer sets out relevant economic parameters for the foreign market which determine whether to remain in the market or leave.

Since the last market entry of the surveyed companies usually occurred recently, it suggests that when observing companies over a longer period of time, further market exits will follow. 


\section{Summary of results}

Of the 100 respondents who are manufacturers of consumer goods, apart from one company, all are still active in the international market. This result may be justified by the nature of the survey. The question revolved around the last entry in an international market.

Most companies have chosen a market entry in the international marketplace on their own. An own market entry often requires investing more than with a no own market entry. Therefore, a market exit often does not seem an option in the planning. It is surprising, however, that little additional expertise in the planning phase of entering the market is resorted to, given the investment in the new international market. This may be related to costs or to reluctance to hire consultants on behalf of companies.

The market entry is usually planned in free markets. Thus, possible sanctions can be ruled out. This may also explain why companies forego planning for a market exit.

The sale of consumer goods occurs largely through retail trade. Therefore, contracts are concluded with these partners. This procedure is intended to simplify access to the new market. From the point of view of the company, market exits appear unlikely.

The study shows that companies with a planned market exit scenario are better prepared for a market exit than companies without. For market exit results to be determined, a further consultation of the companies examined should be undertaken over a longer period of time. 


\section{PLANNING A MARKET EXIT STRATEGY FOR MANUFACTURERS}

\section{Bibliography}

ADM working group of German Market and Social Research Institutes e.V. (2010), Figures 2010, http://www.adm-ev.de [18.02.2012].

Aharoni Y. (1966), The foreign investment decisions process, Harvard University Press, Boston.

Bell J., Crick D., Young S. (2004), Small firm internationalization and business strategy, "International Small Business Journal”, vol. 22 no.1, pp. 23-56.

Brück M. (2011), Der mit dem Drachen tanzt (He who dances with the dragon), „Wirtschaftswoche“, http://www.wiwo.de/unternehmen/henkel-der-mit-dem-drachen-tanzt-seite-3/5156186-3.html [06.09.2011].

Burr W., Stephan M. (2006), Dienstleistungsmanagement (Services sector management), Kohlhammer, Stuttgart.

Büter C. (2010), Internationale Unternehmensführung (International business management), Oldenbourg Verlag, München.

Cezanne W. (2005), Allgemeine Volkswirtschaftslehre (General economics)), 6th edition, Oldenbourg Verlag, München.

Diekmann A. (2010), Empirische Sozialforschung. Grundlagen, Methoden, Anwendungen (Empirical social research. Principles, methods, applications)), 4rd edition, Rowohlt Verlag, Reinbek.

Donges J.B., Freytag A. (2004), Allgemeine Wirtschaftspolitik (General economic policy), 2nd edition, Lucius \& Lucius, Stuttgart.

Dülfer E., Jöstingmeier B. (2008), Internationales Management in unterschiedlichen Kulturbereichen (International management in different cultural areas), 7th edition, Oldenbourg Verlag, München.

Eckrich K. (2003), Die Umsetzung ganzheitlichen Denkens in die Praxis des Projektmanagement (The implementation of holistic thinking in the practice of project management), in: Handbuch Projektmanagemen (Project management handbook), eds. Bernecker M., Eckrich K., Oldenbourg Verlag, München, pp. 35-52.

Emes J., Gruber M. (2008), Die Ideenumsetzung im Rahmen von Marketingsstrategien (The implementation of holistic thinking in the practice of project management), in: Entrepreneurial marketing, eds. Freiling J., Kollmann T., Gabler Verlag, Wiesbaden, pp. 303-322.

Faix W.G., Kisgen S., Lau A., Schulten A., Zywietz T. (2006), Praxishandbuch Außenwirtschaft (Practical handbook of foreign trade), Gabler Verlag, Wiesbaden.

Fischbach R. (1992), Volkswirtschaftslehre. Einführung und Grundlagen (Economics. Introduction and principles), 7th edition, Oldenbourg Verlag, München.

Fuchs M., Apfelthaler G. (2009), Management internationaler Geschäftstätigkeit (Management of international business activities), 2nd edition, Springer Verlag, Vienna. 


\section{Mike DÖRING}

Fuchs W., Unger F. (2007), Management der Marketing-Kommunikation (Management of marketing communication), 4th edition, Springer Verlag, Heidelberg.

Glaum M. (2007), Internationalisierung und Unternehmenserfolg. Theoretische Grundlagen und empirische Befunde (Internationalisation and corporate success. Theoretical foundations and empirical findings), in: Internationalisierung und Unternehmenserfolg (Internationalisation and Corporate Success), eds. Glaum M., Hommel U., Thomaschewski D., Schäffer-Poeschel Verlag, Stuttgart, pp. 329.

Grossekettler H., Hadamitzky A., Lorenz C. (2005), Volkswirtschaftslehre (Economics), UVK Verlagsgesellschaft mbH, Konstanz.

Harms R., Konrad E., Kraus S. (2008), Planung von Unternehmensgründungen. In 5 Schritten von der Geschäftsidee zum Businessplan (Planning for business start-ups. 5 steps from the business idea to the business plan), in: Entrepreneurship, eds. Kraus S, Fink M., Facultas Verlags- und Buchhandels AG, Vienna, pp. 79-93.

Institut für Mittelstandsforschung Bonn (Institute for Small and Medium-sized Business Research Bonn) (2002), KMU-Definition des IfM Bonn (The SME definition of the IfM Bonn], http://www.ifmbonn.org/index.php?id=89 [19.02.2011].

Jenner T. (1994), Internationale Marktbearbeitung. Erfolgreiche Strategien für Konsumgüterhersteller (Working on strategies for international markets. Successful strategies for consumer goods manufacturers), Gabler Verlag, Wiesbaden.

Jenner T. (2000), Angebotspositionierung im Zielmarkt (Market positioning in the target market), in: Markteintritts-Management (Market entry management), ed. Oelsnitz D., Schäffer-Poeschel Verlag, Stuttgart, pp. 121-136.

Kortmann W. (2003), Eine neue Methode für systematische Markt-, Branchen- und Wettbewerbsanalysen (A new method for systematic analyses for market, industry and competition), Duncker \& Humblot GmbH, Berlin.

Kutschker M., Schmid S. (2008), Internationales Management (International management), 6th edition, Oldenbourg Verlag, München.

Kuß A. (2006), Marketing-Einführung (Introduction into marketing), 3rd Edition, Gabler Verlag, Wiesbaden.

Large R. (2009), Strategisches Beschaffungsmanagement (Strategic procurement management), 4th edition, Gabler Verlag, Wiesbaden.

Lehmann-Waffenschmidt B. (2006), Industrieevolution und die New Economy (Industrial evolution and the new economy), Metropolis Verlag, Marburg.

Macharzina K., Wolf J. (2010), Unternehmensführung (Corporate governance), 7th edition, Gabler Verlag, Wiesbaden.

Meffert H., Bolz J. (1994), Internationales Marketing-Management (International marketing management), 2nd edition, Kohlhammer, Stuttgart. 


\section{PLANNING A MARKET EXIT STRATEGY FOR MANUFACTURERS}

Meffert H., Burmann C., Kirchgeorg M. (2008), Marketing, 10th edition, Gabler Verlag, Wiesbaden.

Michaeli R. (2008), Competitive intelligence, Springer Verlag, Heidelberg.

Nagl A. (2011), Der Businessplan (The business plan), 6th edition, Gabler Verlag, Wiesbaden.

Neubert M. (2006), Internationale Markterschließung (International market development), miFachverlag Redline, Landsberg am Lech.

Oelsnitz D. (2000), Markteintritts-Management. Eine Einführung (Market entry market management. An introduction), in: Markteintritts-Management (Market entry management), ed. Oelsnitz D., Schäffer-Poeschel Verlag, Stuttgart, pp. 2-9.

Paier D. (2010), Quantitative Sozialforschung (Quantitative social research), Facultas Verlags- und Buchhandels AG, Wien.

Perlitz M. (2004), Internationales Management (International management), 5th edition, Lucius \& Lucius, Stuttgart.

Porter M.E. (2008), Wettbewerbsstrategie (Competitive strategy), 11th edition, Campus Verlag, Frankfurt.

Renggli G., Martin P. (2006), Regional brand expansion (retail), in: Praxishandbuch Internationales Marketing (Practical handbook of international marketing), ed. Heilmann T., Gabler Verlag, Wiesbaden, pp. 397-409.

Root F.R. (1998), Entry strategy for international markets, Lexington Books, New York.

Ruzzier M., Hisrich R.D., Antoncic B. (2006), SME internationalization research. Past, present, and future, "Journal of Small Business and Enterprise Development", vol. 13 no. 4, pp. 476-497.

Rüdrich G., Kalbfuß W., Weißer K. (2004), Konzeption des Materialgruppenmanagements (Designing material group management), in: Materialgruppenmanagement (Material group management), 2nd edition, eds. Rüdrich G., Kalbfuß W., Weißer K., Gabler Verlag, Wiesbaden, pp. 11-84.

Sander M. (2004), Marketing-Management (Marketing management), Lucius \& Lucius, Stuttgart.

Schmid S. (2006), Strategien der Internationalisierung (Strategies for internationalisation), Oldenbourg Verlag, München.

Schnell R., Hill P.B., Esser E. (2011), Methoden der empirischen Sozialforschung (Methods of empirical social research), 9th edition, Oldenbourg Verlag, München.

Scholl A. (2009), Die Befragung (The survey), 2nd edition, UVK Verlagsgesellschaft, Konstanz.

Siedenbiedel G. (2008), Internationales Management (International Management), Lucius \& Lucius, Stuttgart.

Stiglitz J.E., Walsh C.E. (2010), Mikroökonomie (Microeconomics), 4th edition, Oldenbourg Verlag, München. 


\section{Mike DÖRING}

Von Behr M. (2004), Im Sog der Internationalisierung - Startpunkte, Wege und Ziele kleiner und mittlerer Unternehmen (In the wake of internationalisation - starting points, paths, and targets for small and medium-sized enterprises), in: Internationalisierung kleiner und mittlerer Unternehmen (Internationalisation of small and medium-sized enterprises), eds. von Behr M., Semlinger K., Campus Verlag, Frankfurt, pp. 45-98.

Warzecha B. (2004), Organisationale Planungstheorie (Organisational planning theory), Deutscher Universitätsverlag, Wiesbaden.

Welge M.K., Holtbrügge D. (2006), Internationales Management (International management), 4th edition, Schäffer-Poeschel Verlag, Stuttgart.

Westphal J. (1991), Vertikale Wettbewerbsstrategien in der Konsumgüterindustrie (Vertical competitive strategies in the consumer goods industry), Gabler Verlag, Wiesbaden.

\section{Planowanie strategii wyjścia z rynku przez wytwórców dóbr konsumpcyjnych podczas wchodzenia na rynki zagraniczne}

\section{Streszczenie}

Cel: Dla przedsiębiorstw produkujących dobra konsumpcyjne rynek wewnętrzny jest często zbyt mały, aby zagwarantować długoterminowy sukces. $Z$ tego powodu przedsiębiorstwa podbijają i wchodzą na rynki zagraniczne. Niniejszy artykuł przedstawia proces planowania penetracji rynku dla wybranego rynku zagranicznego, który ukaże możliwość wycofania się, a także omawia, czy scenariusz wyjścia jest planowany przez producentów dóbr konsumpcyjnych oraz kiedy przedsiębiorstwa zaczynają myśleć nad wyjściem z rynku.

Układ / metody badawcze: W pierwszym rzędzie w artykule zawarto przegląd literatury. Na tej podstawie postawiono hipotezy badawcze. Następnie przedstawiono wyniki telefonicznej ankiety przeprowadzonej wśród decydentów w niemieckich przedsiębiorstwach zajmujących się produkcją dóbr konsumpcyjnych.

Wnioski / wyniki: Opracowano model procesu planowania penetracji rynku, przedstawiający obok wejścia na rynek także wyjście z rynku. Ponadto artykuł ukazuje, że wytwórcy dóbr konsumpcyjnych mogą być lepiej przygotowani do wyjścia z rynku aniżeli przedsiębiorstwa bez strategii wyjścia, $\mathrm{w}$ szczególności gdy producenci wyznaczają istotne parametry ekonomiczne dla zagranicznych rynków, determinujące decyzję o pozostaniu lub wycofaniu się z rynku.

Oryginalność / wartość artykułu: Podczas analizy literatury poświęconej procesowi planowania wejścia na rynek jasne staje się, że strategia wyjścia nie podlega planowaniu. Może to oznaczać, że autorzy nie rozważają wyjścia z rynku i / lub przypuszczają, że jest to najgorszy przypadek w ich założeniach dotyczących wejścia na rynek.

Implikacje badań: Ostatnie wejścia na rynek ankietowanych przedsiębiorstw zwykle miały miejsce niedawno. Aby określić wyniki wyjścia $\mathrm{z}$ rynku, niezbędne jest podjęcie dalszych konsultacji $\mathrm{z}$ badanymi przedsiębiorstwami w dłuższej perspektywie czasowej.

Słowa kluczowe: Wytwórczy dóbr konsumpcyjnych, rynki zagraniczne, proces planowania dla penetracji rynki, wyjśsie z rynku

JEL: L20, L66, L67, L68. 